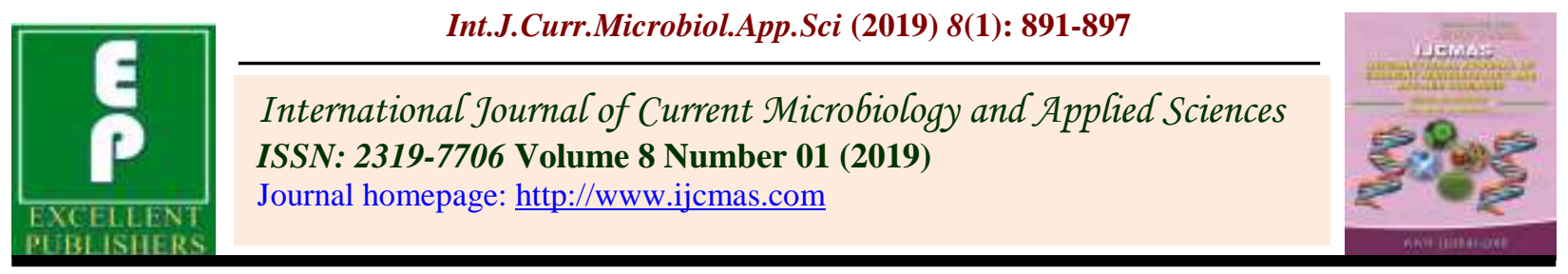

Original Research Article

https://doi.org/10.20546/ijcmas.2019.801.096

\title{
Assessment of Environmental Flow Requirement using Environmental Management Classes-Flow Duration Curve for Narmada River
}

\author{
Alpna Dubey ${ }^{*}$, Omkar Singh ${ }^{2}$, Shashank Shekhar ${ }^{3}$ and Chwadaka Pohshna ${ }^{4}$ \\ ${ }^{1}$ College of Agricultural Engineering, J.N.K.V.V. Jabalpur (M.P.), India \\ ${ }^{2}$ National Institute of Hydrology, Roorkee-247 667 (Uttarakhand), India \\ ${ }^{3}$ College of Agricultural Engineering, Bapatla, (A.P.), India \\ ${ }^{4}$ College of Agricultural Engineering and Post-Harvest Technology Ranipool (Sikkim), India \\ *Corresponding author
}

A B S T R A C T

\begin{tabular}{|l|}
\hline Ke y w o r d s \\
$\begin{array}{l}\text { Environmental } \\
\text { flow, Riverine } \\
\text { ecosystem, River } \\
\text { basin, Water quality }\end{array}$ \\
\hline Article Info \\
\hline $\begin{array}{l}\text { Accepted: } \\
\text { 07 December } 2018 \\
\text { Available Online: } \\
\text { 10 January } 2019\end{array}$ \\
\hline
\end{tabular}

The Narmada is the largest west-flowing peninsular river ranks seventh in terms of water discharge $\left(38 \mathrm{~km}^{3} / \mathrm{yr}\right)$ in India. A number of dams have been constructed on the Narmada River and its tributaries, mainly for the purpose of electric power generation, irrigation and for controlling floods. The objective of this paper is to calculate minimum flow of Narmada River which is necessary to protect ecosystem and biodiversity at downstream site of dam which is constructed across Narmada River and its tributaries. In the present study, the flow data was analyzed for four stations (Sandia, Barman, Dindori, and Manot gauging stations) in Narmada basin using Global Environmental Flow Calculator (GEFC) developed by International Water Management Institute (IWMI) Shri Lanka. It is built around a period-of-record flow duration curve (FDC) accumulative probability distribution function of flows and includes several subsequent steps. The environmental flow requirement (EFR) for protection of biodiversity and ecosystem of River minimum flow should be $46 \%$ of MAR (Mean Annual Runoff) at barman station, $45.1 \%$ of MAF at Sandia station and $36.1 \%$ at Dindori station and $24.3 \%$ of MAR at Manot station of Narmada basin.

\section{Introduction}

Environmental flows are the water that is left in a river, or released into it (e.g. from a reservoir), in order to maintain valued features of the ecosystem (Kingand Tharme, 1993; Richter et al., 1997). It refers to the water considered sufficient for protecting the structure and function of an ecosystem and its dependent species. This means enough water is left in rivers, which is managed to ensure downstream environmental, social and economic benefits. Environmental flow requirements are those needed to help maintain downstream ecosystems, renewable natural resource production systems and associated livelihoods (Iyer, 2005). As such, environmental flow requirement is a compromise between water resources development and maintenance of a river in ecologically acceptable or agreed conditions (Acreman and Dunbar, 2004). By constructing dams and weirs and abstracting water, man tried to exploit the river mainly for 
economical purposes. During the middle of the last century people became aware of the fact that these interventions in the river flow regime have important negative ecological and social effects in the downstream riverine and coastal areas. The practice of EFR's began as a commitment to ensuring a 'minimum flow' in the river, often arbitrarily fixed at $10 \%$ of the mean annual runoff (Brinkerhoff, 2000). But more and more scientific evidence and experience is available that questions the 'minimum flow' approach and there is now a general opinion that for safeguarding essential downstream environmental condition the dynamics of the river flow should be taken into account. People living along rivers depend for their livelihood to various degrees on functions of the river ecosystem and, since river flow is an important parameter in the functioning of river ecosystems, these people are thus affected by changes in the flow regime. To make equitable decisions in river basin management insight is required in the relationship between river flows and the livelihood of people living along rivers.

Various methods are available for estimating EFR of rivers and broadly can be grouped under hydrological index method, hydraulic rating methods, habitat simulation methodologies and holistic methodologies (Richardson, 1986; Tharme, 2003; Smakhtin and Erivagama, 2008; Dubey et al., 2013). In the present paper, EFR of few reaches of Narmada River has been assessed using Global Environmental Flow Calculator (GEFC, IWMI).

\section{Materials and Methods}

\section{Study area}

The Narmada is the largest west-flowing peninsular river, ranks seventh in terms of water discharge $\left(38 \mathrm{~km}^{3} /\right.$ year $)$ and drainage area $\left(98,796 \mathrm{~km}^{2}\right)$ in Indian subcontinent.
The river rises as groundwater seepage from Narmada Kund (1057 m above mean sea level) at Amarkantak on the eastern fringe of the Maikala Plateau. The Narmada is fed by 41 tributaries, 22 are on the left bank and rest is on the right bank of the mainstream $(\mathrm{CPCB}$, 2001). A number of dams have been constructed on the Narmada River and its tributaries, mainly for the purpose of electric power generation, irrigation and for controlling floods.

According to the Narmada Control Authority (NCA) the river drains an area of $98,796 \mathrm{~km}^{2}$ out of which nearly $86 \%$ lies in Madhya Pradesh, $1 \%$ in Chhattisgarh, 2\% in Maharashtra and $11 \%$ in Gujarat.

The Narmada basin is dominated by humid tropical climate. Maximum (average) temperature is observed during May (40-42 ${ }^{\circ} \mathrm{C}$ ) and minimum (average) is recorded in January $\left(8-13 \quad{ }^{\circ} \mathrm{C}\right)$. The majority of precipitation in the basin takes place during the southwest monsoon season from middle June to October, accounting for approximately $85-95 \%$ of the annual precipitation. Approximately $60 \%$ of the annual rainfall is received during July and August. The mean annual rainfall in the basin is approximately $1178 \mathrm{~mm}$, though the rainfall distribution is not uniform and varies between 600 and 1800 mm.

Four gauging station upper Narmda basin (Sandia, Barman, Dindori and Manot) were selected for the study shown in Figure 1, whereas details of hydrological characteristics and mean monthly flow are given in Table 1 and 2 respectively. Long term discharge data (10-year data from 1999-2009) collected from four gauging sites Manot, Barman and Sandia of Narmada River (CWC) for estimating EFR. In this paper the Environmental Management Class-Flow Duration Curve (EMC-FDC) desktop approach based on hydrological data was used to estimate the environmental flow 
at a selected site on Narmada River basin with the help of Global Environmental Flow Calculator. In this methodology, seventeen fixed percentage points are taken for the computation of dependable flows. The Global Environmental Flow Calculator (GEFC) is a software package for desktop rapid assessment of Environmental Flows (EFs). The EF estimation technique in GEFC is using monthly time step series reflecting "natural"/unregulated flow conditions and its corresponding Flow Duration Curve (FDC), a cumulative distribution function of flows. The FDC is represented by 17 percentage points on the probability $(\mathrm{X})$ axis. EFs aim to maintain an ecosystem in, or upgrade it to some prescribed or negotiated condition "Environmental Management Class (EMC)." The higher the EMC, the more water is needed for ecosystem maintenance and more flow variability needs to be preserved. Six EMCs are used in GEFC, ranging from "Unmodified" to "Critically Modified." Each EMC is represented by its unique FDC. The FDC for each class is determined by the lateral shift of the original reference FDC to the left along the probability (X) axis by one percentage point. Each EMC is effectively an EF scenario. The EMC best suited for the river in question may be selected-based on expert judgment. A FDC established for each EMC can be converted into an EF time series.

\section{Results and Discussion}

The Environmental flow requirement (EFR)of Narmada River at four locations (Dindori, Manot, Barman and Sandia) has estimated using GFEC for various EMC's are given in Environmental flow requirement with mean monthly runoff for given EMC's from A to F class was varying from 69.3-17.6\% for Sandia station, $19.2 \%$ to68.8\% for Barman station and 65 to $5 \%$ for Dindori station, 61 to $1.4 \%$ for Manot gauging (Table 3). It is evident from the Table 3 EMC class $\mathrm{A}$ is required more MAR as compere to other class. Flow Duration Curve of different EMC classes of Narmada River at different stations using probability distribution of discharge at seventeen fixed points are shown in Figure 2 for Sandia, Barman, Dindori and Manot station, respectively. It is evident from the Figure 2 the natural flow in Sandia gauging station was higher reached upto $23000 \mathrm{MCM}$ followed by Barman (15000 MCM), Manot (2500 MCM) and Dindori (900 MCM), respectively. According to FDC probability of highest flow was $0.01 \%$ for all EMCs with different flow varied from EMC-A to EMC-F. Whereas, lowest flow was $99.99 \%$ for all EMCs.

Figure 3 represents monthly time series of flow with 6 Environmental Flow Management classes at different gauging stations. Environmental management class ' $A$ ' is not right suggestion for Narmada River because this class is very near to natural flow which may create some hardship to the Dam authorities for meeting water demand for Hydropower generation and other uses (Figure 2-3). If we adopted EMC ' $D$ ' ' $E$ ' ' $F$ ' there are very low flow suggested by the GFEC and this low flow is also not good for maintaining River water quality and aquatic life. Further EMC ' $\mathrm{B}$ ' or EMC ' $\mathrm{C}$ ' may be considered as minimum flow for maintaining water quality and aquatic life at the downstream side of the Narmda river. Monthly minimum flow required at Dindori station for $E M C$ ' $\mathrm{B}$ ' is $14.38 \mathrm{~m}^{3} / \mathrm{s}$ (453 MCM) and for EMC ' $\mathrm{C}$ ' is $8 \mathrm{~m}^{3} / \mathrm{s}$ (252MCM) where as for Manot station flow should be $28.13 \mathrm{~m}^{3} / \mathrm{s}$ (887.19 MCM), and $12.73 \mathrm{~m}^{3} / \mathrm{s}$ (401.61 MCM)for EMC ' $\mathrm{B}$ ' and ' $\mathrm{C}$ ', respectively. For Barman station minimum water required for EMC ' $\mathrm{B}$ ' is $180.5 \mathrm{~m}^{3} / \mathrm{s}(5692.5 \mathrm{MCM})$ and for EMC ' $\mathrm{C}$ ' is $133 \mathrm{~m}^{3} / \mathrm{s}$ (4207.5 MCM) whereas at Sandia station flow should be $224.6 \mathrm{~m}^{3} / \mathrm{s}$ (7084MCM) and $160 \mathrm{~m}^{3} / \mathrm{s}$ (5037.4MCM) for EMC ' $\mathrm{B}$ ' and 'C', respectively. 
Table.1 Location-wise hydrological characteristics of the Narmada mainstream

\begin{tabular}{|c|c|c|c|c|c|c|c|c|c|}
\hline $\begin{array}{l}\text { Sampling } \\
\text { location }\end{array}$ & $\begin{array}{l}\text { Location } \\
\text { code }\end{array}$ & $\begin{array}{l}\text { Lat.- } \\
\mathbf{N}\end{array}$ & $\begin{array}{l}\text { Long.- } \\
\mathrm{E}\end{array}$ & Elevation(m) & $\begin{array}{l}\text { Drainage } \\
\text { area up to } \\
\text { station }\left(\mathrm{km}^{2}\right)\end{array}$ & $\begin{array}{l}\text { Length of } \\
\text { river up } \\
\text { to station } \\
(\mathrm{km})\end{array}$ & $\begin{array}{l}\text { Annual } \\
\text { rainfall } \\
(\mathrm{mm})\end{array}$ & $\begin{array}{l}\text { Mean } \\
\text { annual } \\
\text { temp }\left({ }^{\circ} \mathrm{C}\right)\end{array}$ & Runoff(mm/year) \\
\hline Dindori & $\mathrm{N} 2$ & $22^{\circ} 57^{\prime}$ & $81^{\circ} 50$ & 666.1 & 2292 & 95 & 1493 & 23.0 & 594 \\
\hline Manot & N3 & $22^{\circ} 44^{\prime}$ & $80^{\circ} 31^{\prime}$ & 451.6 & 4467 & 218 & 1517 & 25.1 & 846 \\
\hline Barman & N6 & $23^{\circ} 01^{\prime}$ & $79^{\circ} 00^{\prime}$ & 319.1 & 26,453 & 504 & 1241 & 25.3 & 550 \\
\hline Sandia & N7 & $22^{\circ} 50^{\prime}$ & $78^{\circ} 21^{\prime}$ & 308.6 & 33,954 & 594 & 1150 & 25.3 & 563 \\
\hline
\end{tabular}

Table.2 Mean monthly flow for various sites in Narmada River basin

\begin{tabular}{|c|c|c|c|c|c|c|c|c|c|c|c|c|c|}
\hline \multirow[t]{2}{*}{ Site } & \multirow{2}{*}{$\begin{array}{l}\text { MAF } \\
\text { m³ec }^{3} / \mathrm{sec}\end{array}$} & \multicolumn{12}{|c|}{ Mean monthly flow ( $\mathrm{m}^{3} / \mathrm{sec}$-day) } \\
\hline & & Jan & Feb & Mar & Apr & May & Jun & Jul & Aug & Sept & Oct & Nov & Dec \\
\hline Sandia & 506 & 212 & 178 & 140 & 137 & 125 & 163.7 & 840.4 & 1621.4 & 1636.5 & 494 & 277.4 & 247.5 \\
\hline Barman & 397.8 & 186.2 & 154 & 124 & 119 & 101 & 123.8 & 646.5 & 1302.8 & 1179.6 & 391.8 & 236 & 208.6 \\
\hline Dindori & 40.5 & 6.1 & 5.6 & 3.8 & 2.2 & 1.5 & 37.8 & 116.4 & 164 & 98.4 & 29.5 & 12.5 & 7.78 \\
\hline Manot & 117.3 & 7.3 & 7 & 3.5 & 1.93 & 0.7 & 39.3 & 270.1 & 700.2 & 279.2 & 69.2 & 19.8 & 9.99 \\
\hline
\end{tabular}

*MAF: Mean annual flow 
Table.3 EFR with different EMC's at Sandia, Barman, Dindori, and Manotgauging stations

\begin{tabular}{|c|c|c|c|c|c|c|c|c|}
\hline & \multicolumn{2}{|l|}{ Sandia } & \multicolumn{2}{|c|}{ Barman } & \multicolumn{2}{|c|}{ Dindori } & \multicolumn{2}{|c|}{ Manot } \\
\hline $\begin{array}{l}\text { EMC } \\
\text { Class }\end{array}$ & $\begin{array}{l}\% \text { of } \\
\text { natural } \\
\text { MAR }\end{array}$ & $\begin{array}{l}\text { EFR } \\
(\mathrm{MCM})\end{array}$ & $\begin{array}{l}\% \text { of } \\
\text { natural } \\
\text { MAR }\end{array}$ & $\begin{array}{l}\text { EFR } \\
(\mathrm{MCM})\end{array}$ & $\begin{array}{l}\% \text { of } \\
\text { natural } \\
\text { MAR }\end{array}$ & $\begin{array}{l}\text { EFR } \\
(\mathrm{MCM})\end{array}$ & $\begin{array}{l}\% \text { of } \\
\text { natural } \\
\text { MAR }\end{array}$ & $\begin{array}{l}\text { EFR } \\
(\mathrm{MCM})\end{array}$ \\
\hline $\mathbf{A}$ & 69.3 & 10,862 & 68.8 & ( & 65.4 & 819 & 61.3 & $2,227.1$ \\
\hline B & 45.1 & 7,084 & 46 & $5,692.5$ & 36.1 & 453.6 & 24.3 & 887.19 \\
\hline C & 32.4 & $5,037.4$ & 34 & $4,207.5$ & 19.9 & 252 & 11.2 & 401.61 \\
\hline D & 25.6 & 4,030 & 27.5 & 3403.1 & 11.4 & 143.64 & 5.3 & 193.5 \\
\hline $\mathbf{E}$ & 21.1 & 3305.82 & 22 & $2,821.5$ & 7.2 & 90.72 & 2.6 & 94.93 \\
\hline F & 17.6 & $2,770.6$ & 19.2 & 2376 & 5 & 63 & 1.4 & 51.11 \\
\hline
\end{tabular}

Fig.1 Map of Narmada River and selected gauging stations and major tributary

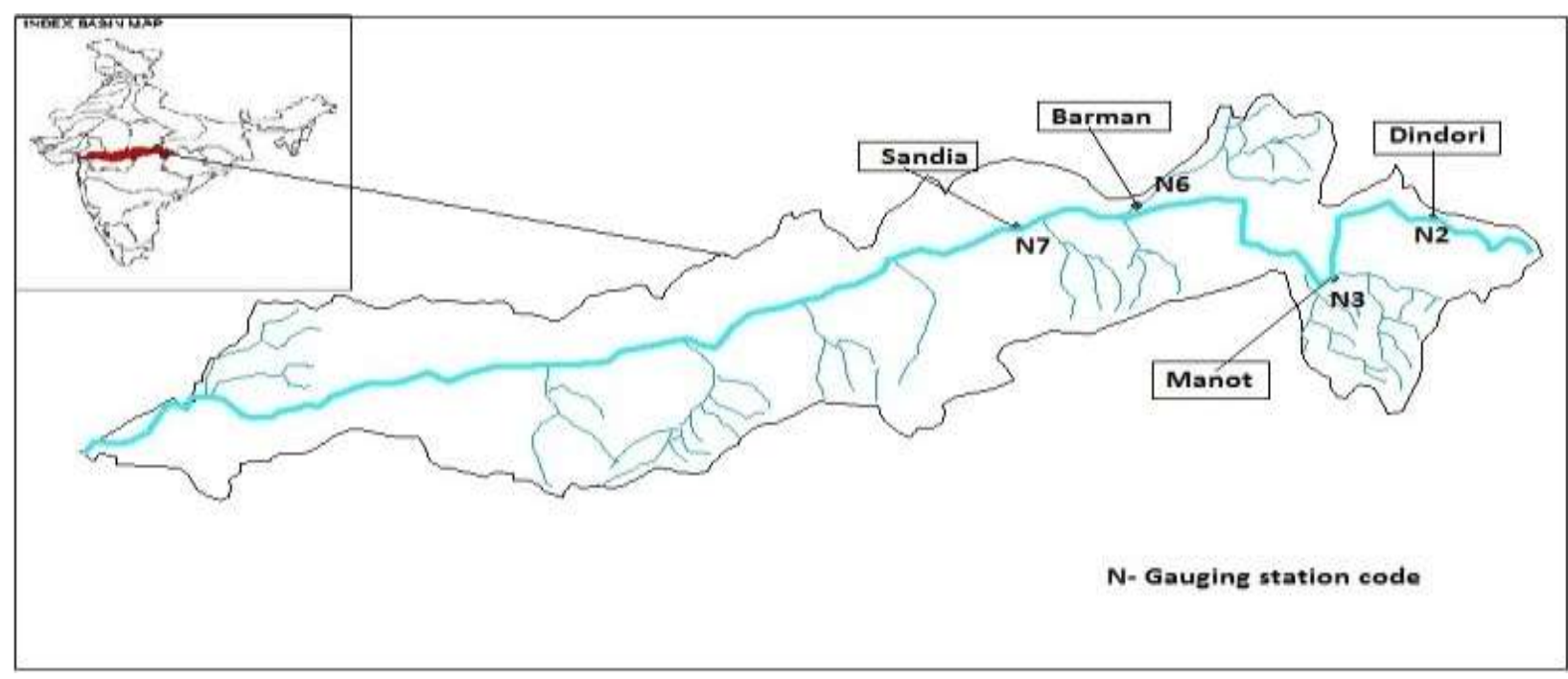

Fig.2 Flow duration curves for different Environmental Management classes of (a) Sandia (b) Barman (c) Dindori, and (d) Manotgauging station
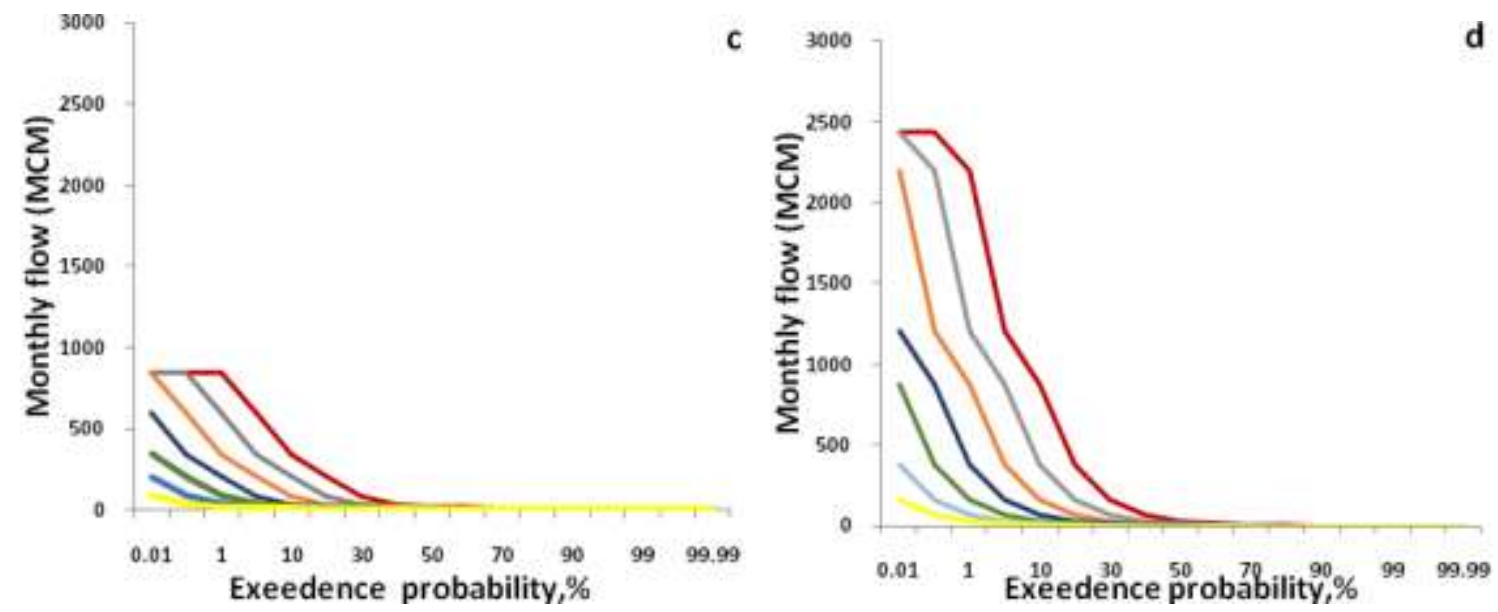
Fig.3 Monthly time series of flow with 6 Environmental Flow Management classes at (a) Sandia, (b) Barman, (c) Dindori, and (d) Manot station

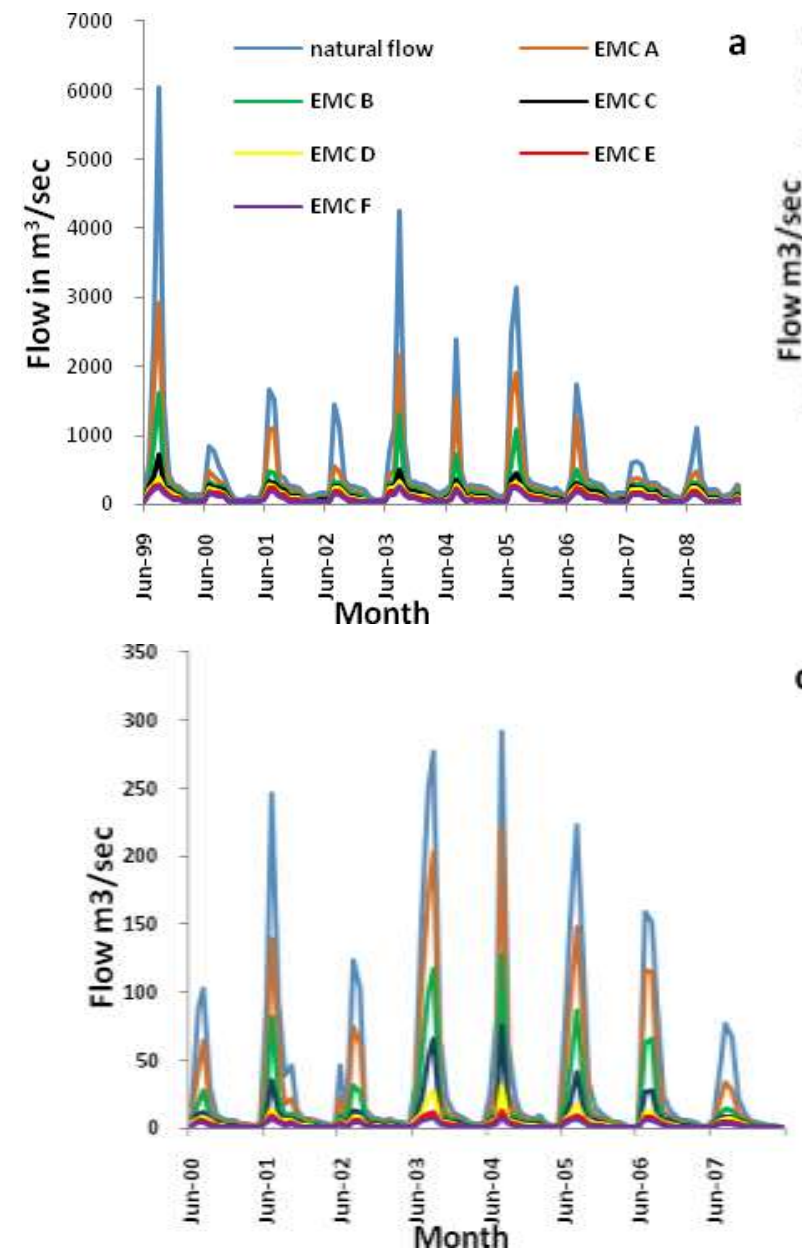

\section{References}

Acreman, M.C. and Dunbar, M.J., (2004). Defining environmental river flow requirements? A review. Hydrology and Earth System Sciences Discussions, 8(5), pp.861-876.

Brinkerhoff JM. (2002) Global public policy, partnership, and the case of the World Commission on Dams. Public Administration Review. 62(3):324-36.

CPCB (2001) Central Pollution Control Board, Environmental Atlas of India. National Atlas \& Thematic Mapping Organization, Kolkata.

Dubey, A., Kant, D., Singh, O. and Pandey,

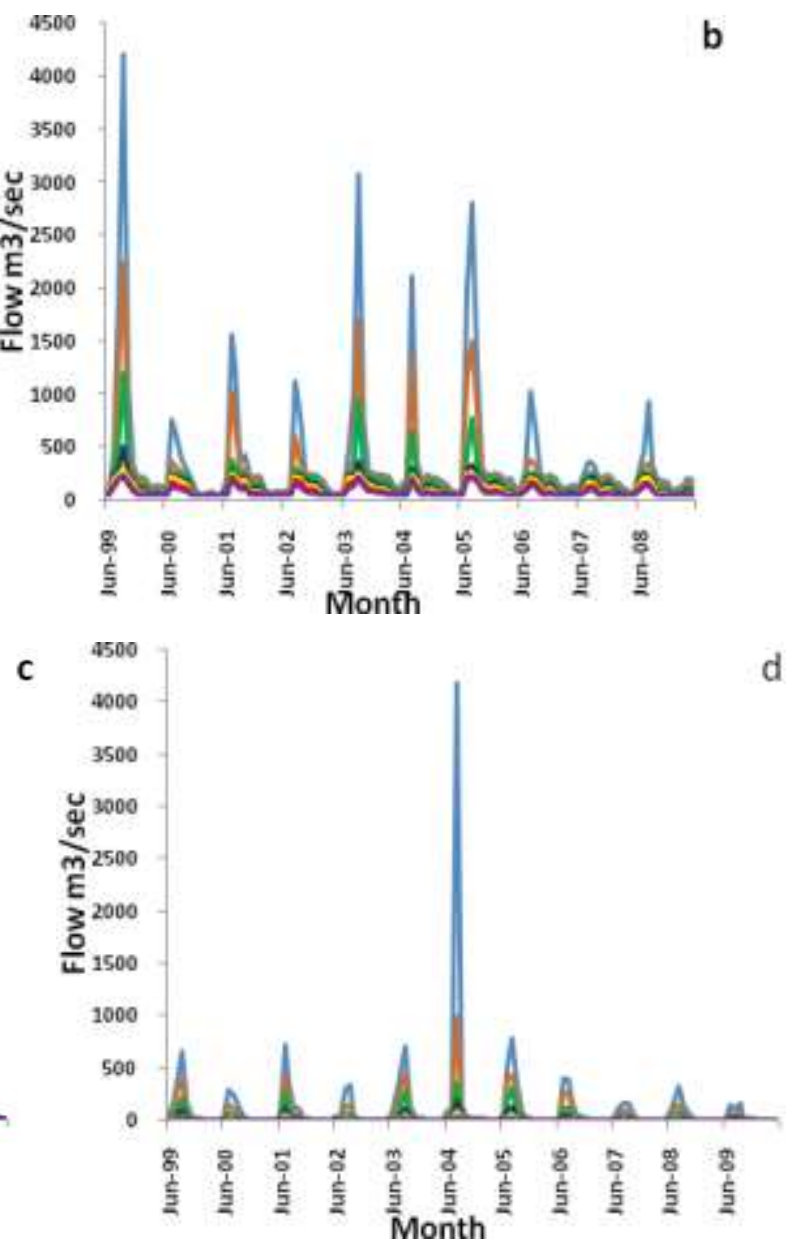

R.P., (2013). A comparative study of environmental flow requirement approaches using hydrological index methods. J. Indian Water Resour. Soc, 33(3), pp.20-27.

Iyer, R.R., (2005), March. The notion of environmental flows: a caution NIE. In IWMI Workshop on Environmental Flows, New Delhi (pp. 23-24).

King, J.M. and Tharme, R.E., (1993). Assessment of the instream flow incremental methodology, and initial development of alternative instream flow methodologies for South Africa. Water Research Commission.

Richardson, B.A., (1986). Evaluation of 
instream flow methodologies for freshwater fish in New South Wales. Stream Protection, the Management of Rivers for Instream Use. Water Studies Centre, Chisholm Institute of Technology, East Caulfield, pp.143-167.

Richter, B., Baumgartner, J., Wigington, R. and Braun, D., (1997). How much water does a river need?. Freshwater biology, 37(1), pp. 231-249.

Smakhtin VU, Eriyagama N. (2008)
Developing a software package for global desktop assessment of environmental flows. Environmental Modelling \& Software. 1; 23(12):1396406.

Tharme, R.E., (2003). A global perspective on environmental flow assessment: emerging trends in the development and application of environmental flow methodologies for rivers. River research and applications, 19(5-6), pp. 397-441.

\section{How to cite this article:}

Alpna Dubey, Omkar Singh, Shashank Shekhar and Chwadaka Pohshna. 2019. Assessment of Environmental Flow Requirement using Environmental Management Classes-Flow Duration Curve for Narmada River. Int.J.Curr.Microbiol.App.Sci. 8(01): 891-897. doi: https://doi.org/10.20546/ijcmas.2019.801.096 